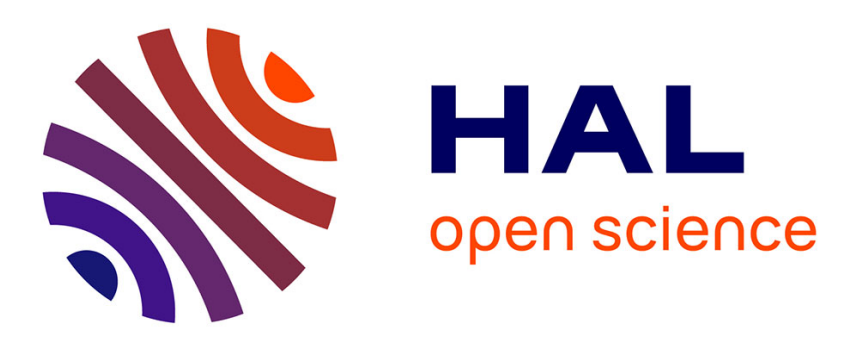

\title{
The Cévennes-Vivarais Mediterranean Hydrometeorological Observatory database
}

B. Boudevillain, G. Delrieu, B. Galabertier, L. Bonnifait, L. Bouilloud, P.E. Kirstetter, M.L. Mosini

\section{- To cite this version:}

B. Boudevillain, G. Delrieu, B. Galabertier, L. Bonnifait, L. Bouilloud, et al.. The Cévennes-Vivarais Mediterranean Hydrometeorological Observatory database. Water Resources Research, 2011, 47, pp.W07701. 10.1029/2010WR010353 . insu-00648073

\section{HAL Id: insu-00648073 \\ https://hal-insu.archives-ouvertes.fr/insu-00648073}

Submitted on 2 Mar 2021

HAL is a multi-disciplinary open access archive for the deposit and dissemination of scientific research documents, whether they are published or not. The documents may come from teaching and research institutions in France or abroad, or from public or private research centers.
L'archive ouverte pluridisciplinaire HAL, est destinée au dépôt et à la diffusion de documents scientifiques de niveau recherche, publiés ou non, émanant des établissements d'enseignement et de recherche français ou étrangers, des laboratoires publics ou privés. 


\title{
The Cévennes-Vivarais Mediterranean Hydrometeorological Observatory database
}

\author{
Brice Boudevillain, ${ }^{1}$ Guy Delrieu, ${ }^{1}$ Bruno Galabertier, ${ }^{1}$ Laurent Bonnifait, ${ }^{1}$ \\ Ludovic Bouilloud, ${ }^{1}$ Pierre-Emmanuel Kirstetter, ${ }^{1}$ and Marie-Laure Mosini ${ }^{2}$ \\ Received 23 December 2010; revised 1 April 2011; accepted 20 April 2011; published 8 July 2011.
}

[1] Intense rain events frequently result in devastating flash floods in Mediterranean regions. To improve the understanding and prediction of these phenomena, the CévennesVivarais Mediterranean Hydrometeorological Observatory (CVMHO) was set up in 2000. The observation strategies deployed include the detailed and long-lasting ( $>10$ years) observation in the Cévennes-Vivarais region (France) using both operational observation systems and research instrumentation. The present note describes the procedures implemented by CVMHO to critically analyze and generate hydrometeorological products for research. The related data can be viewed or downloaded via the Système d'Extraction et de Visualisation des Données de l'Observatoire en Ligne (SEVnOL) interface on the CVMHO Web site.

Citation: Boudevillain, B., G. Delrieu, B. Galabertier, L. Bonnifait, L. Bouilloud, P.-E. Kirstetter, and M.-L. Mosini (2011), The Cévennes-Vivarais Mediterranean Hydrometeorological Observatory database, Water Resour. Res., 47, W07701, doi:10.1029/2010WR010353.

\section{Introduction}

\subsection{Context}

[2] Mediterranean regions are frequently prone to heavy rainfall that may produce damaging flash floods in fall. From a meteorological perspective, this can be explained by the simultaneous presence of a number of factors that are propitious to extreme precipitation events [Nuissier et al., 2008].

[3] 1. At the end of summer, the warm Mediterranean Sea heats and feeds the lowest levels of the troposphere with moisture through air-sea sensible and latent-heat fluxes.

[4] 2. A strong synoptic-scale trough over Western Europe or a closed cyclone at upper levels over Spain often generates a flow advecting the warm and moist air masses from the sea toward the coast, destabilizing the air column.

[5] 3. The steep and particular orography of the Mediterranean region triggers convection and channelizes the hot and humid air masses.

[6] Our knowledge of weather conditions leading to flooding has improved over the years but it is still difficult to reliably forecast rain locations and amounts [Nuissier et al., 2008].

[7] From a hydrological perspective, these flash floods can be explained by the fact that Mediterranean watersheds are often mountainous and/or urbanized, thereby accelerating runoff. The nature of soils and characteristics related to

\footnotetext{
${ }^{1}$ UJF Grenoble 1/CNRS/G-INP/IRD, Laboratoire d'Étude des Transferts en Hydrologie et Environnement, UMR 5564, Grenoble, France.

${ }^{2}$ Département Géotechnique, Eau and Risques, IFSTTAR, Bouguenais, France.
}

Copyright 2011 by the American Geophysical Union. 0043-1397/11/2010WR010353 geology, land use (and its changes) and initial humidity strongly influence the occurrence of flash floods [Braud et al., 2010]. The relationship between cumulative rainfall and the occurrence of flooding is highly nonlinear and remains a subject of research [Delrieu et al., 2009a; Marchi et al., 2010]. The French Mediterranean coast, in particular the Cévennes-Vivarais region, is one of the main regions concerned by flash floods in Europe. One of the most dramatic event occurred on 8-9 September 2002, causing 24 casualties and economic damage evaluated at 1.2 billion Euros [Delrieu et al., 2005]. During this event, $24 \mathrm{~h}$ rain amounts greater than $200 \mathrm{~mm}$ were observed over $5500 \mathrm{~km}^{2}$ with up to $600-700 \mathrm{~mm}$ at some locations. The social and economic vulnerability of these regions is high due to the presence of urbanized areas and tourism during summer and fall. The main challenge for research and operational services is to improve forecasting of these events both in terms of meteorology and hydrology. This requires better documentation and a better understanding of the phenomena involved.

\subsection{The Cévennes-Vivarais Mediterranean Hydrometeorological Observatory}

[8] To improve the understanding and modeling of intense rain events and flash floods, the Cévennes-Vivarais Mediterranean Hydrometeorological Observatory (CVMHO; OHMCV is the French acronym) was set up in 2000. A primary objective of the observatory is to bring together the skills of meteorologists and hydrologists, modelers and instrumentalists, researchers and practitioners, to cope with these hard to predict events. Indeed, flash floods are locally rare events which are difficult to monitor due to their intensity and the space-time characteristic scales. CVMHO aims at building an integrated database for such extreme events (covering both hydrometeorological input and output), and based on the combination of conventional and 

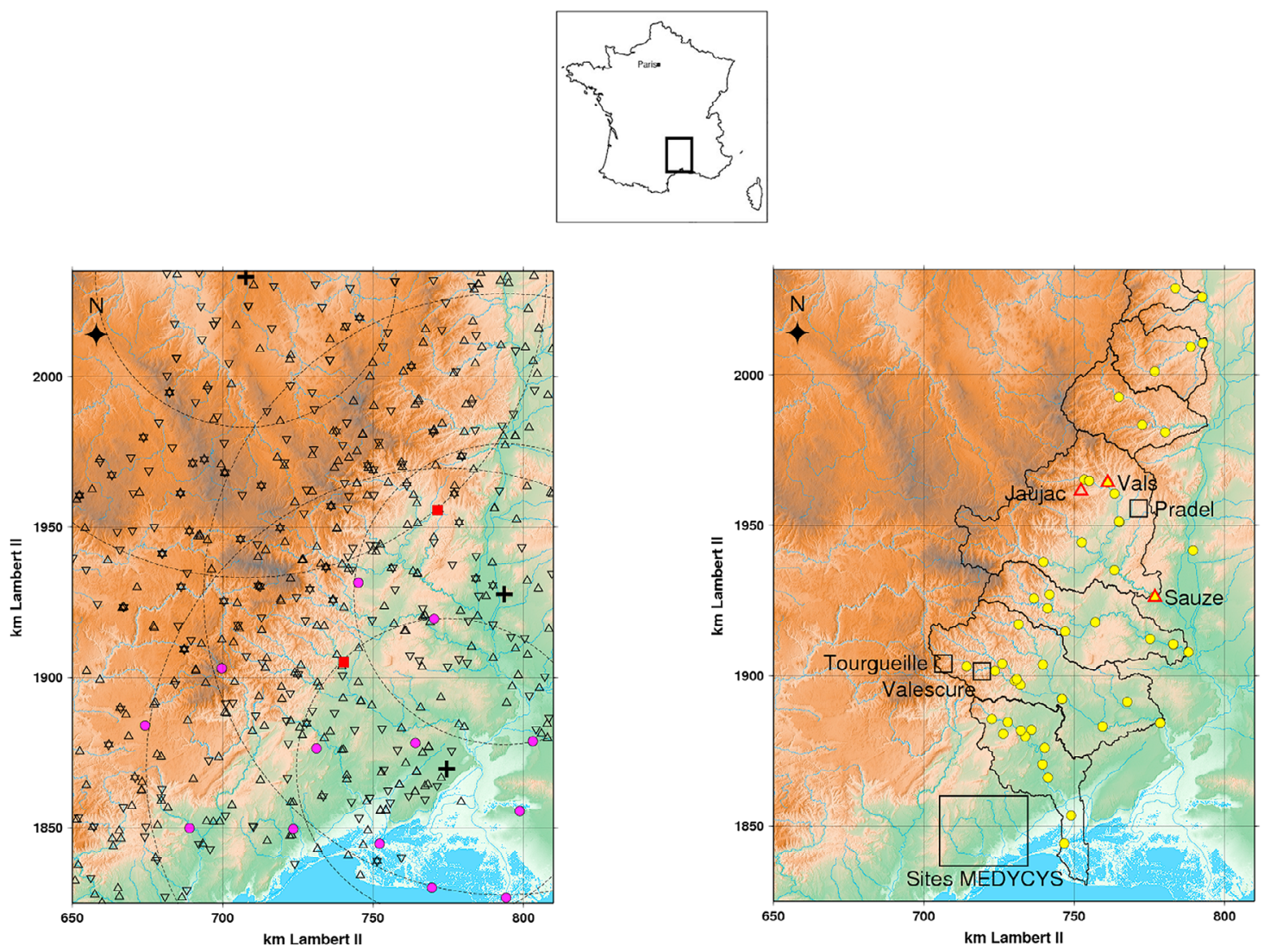

Figure 1. (top) Location of CVMHO pilot site. (bottom left) Water vapor and precipitation measurement stations: GPS stations (purple dots), hourly rain gauges (open inverted triangles), daily rain gauges (triangles), disdrometers (red squares), and ARAMIS weather radar network (black pluses and $50 \mathrm{~km}$ range markers). (bottom right) Hydrological stations within the major watersheds of the Vivarais and Cévennes regions (black boundaries): operational hydrometric stations (yellow dots), LS-PIV gauging stations (red triangles), and hydrological supersites (black squares).

specific observation. CVMHO develops three observation strategies: (1) detailed, long-lasting, and modern hydrometeorological observation over part of the region of interest, the Cévennes-Vivarais region, for the purpose of process studies and the improvement and assessment of coupled hydrometeorological predictive models; (2) multidisciplinary postflood investigations following the most extreme events wherever they occur in the Mediterranean region [Delrieu et al., 2005; Ruin et al., 2008; Gaume and Borga, 2008 ] to document and analyze the physical processes and societal factors involved; and (3) use of historical information available on past floods [Sheffer et al., 2003; Naulet et al., 2005; Cour and Lang, 2008] to better characterize the frequency of extreme hydrometeorological events and possible trends in a changing climate. For each of these strategies, databases have been or will be set up. This note focuses on the description of the database of the first observation strategy.

[9] Currently available data from operational observation systems and research experiments are presented in section 2 . The critical analysis procedure and the generation of hydrometeorological products for research are discussed in sections 3 and 4, respectively. The data and products available for viewing and extraction on the CVMHO Web site are described in section 5. Section 6 briefly deals with future developments and perspectives.

\section{Data}

[10] Since the Cévennes-Vivarais region is particularly subject to flash floods, it is already relatively (compared to other regions) well instrumented with operational observation systems. Figure 1 shows the location of the CévennesVivarais region in France as well as the meteorological and hydrological observation networks. CVMHO has gathered and put in a common format data from these systems each fall since 2000 in order to compile a broad sample of rain events from a relatively stable and dense observation system. For the 9 fall seasons from 2000 to 2008,213 and 124 days with rain amounts greater than 50 and $100 \mathrm{~mm}$, respectively, have been observed at different locations in the region of interest.

[11] The data collected concern the following.

[12] 1. Rainfall time series were collected from MétéoFrance, Électricité de France (EDF) and the Service de Prévision des Crues du Grand-Delta (SPC-GD, one of the 22 flood forecasting services in France) since 2006 and from 
two other French agencies (DDE) until 2005. Within the $160 \times 210 \mathrm{~km}^{2}$ Cévennes-Vivarais window, there were about 162 daily rain gauges, 187 hourly rain gauges, and 65 rain gauges with a 5 min time step in 2008 .

[13] 2. River water level and discharge time series, as well as rating curves, were collected from the gauged rivers of the Cévennes-Vivarais region from SPC-GD since 2006, and previously from four other French agencies in charge of the environment (DIREN) and flood forecasting (DDE). The hydrometric network is presently composed of 45 water level stations with a 5 min time step;

[14] 3. Radar data were collected from the Bollène, Sembadel and Nîmes radar systems of the Météo France ARAMIS network. The time step is $5 \mathrm{~min}$ and the spatial resolution is $1 \mathrm{~km}^{2}$. Since 2002, all radars have gradually adopted $3-\mathrm{D}$ scanning protocols [Tabary, 2007]. Since 2008, all radars have Doppler capability and the Nîmes radar system has dual polarization diversity capability.

\section{Data Critical Analysis}

[15] CVMHO provides significant value added to operational data in terms of data critical analysis. Data critical analysis is already performed by each data producer. However, a critical analysis carried out on the whole data set coming from different networks significantly improves the detection of erroneous data.

[16] Concerning rainfall data, CVMHO uses a geostatistical data quality control technique [Kirstetter et al., 2010] to identify rain gauges that present abnormal differences in terms of rain amounts with their neighbors. The suspicious rain gauge time series are checked individually in a second step. It is planned to refine the analysis, presently carried out at the daily time step, by shortening the time step and by comparing the rainfall time series observed by rain gauges and the various weather radars.

[17] Concerning water level and discharge data, time series are examined by detecting abnormal values, such as major discontinuities in the time series, often due to water level gauge malfunctions. Discharges are then estimated using operational rating curves that are made available on the CVMHO Web site as well. Discharge values of nested catchments are cross checked for consistency in terms of peak flow times and volumes (discharges normally increase and peak times are generally delayed from upstream to downstream). Any inconsistencies detected are then investigated and are often discussed with the data producers. Values that cannot be corrected are discarded. A critical point is related to the estimate of high and extreme discharges for which the rating curves are generally not documented for (gaugings are generally not carried out during such events to ensure the safety of operators and equipment). One-dimensional hydraulic modeling is being implemented over all the discharge stations to harmonize the rating curves [Lang et al., 2010]. Moreover new gauging techniques are progressively implemented to improve the situation (section 6).

[18] Concerning radar data, a special agreement has been made with Météo-France to give CVMHO access to raw 3-D data (including mean reflectivity with and without clutter filtering, pulse-to-pulse variability of reflectivity) in addition to the operational rain products. A number of preprocessing operations are performed to (1) check electronic calibration stability and geographical positioning thanks to ground clutter [Pellarin et al., 2002] and (2) characterize dry weather noise and clutter [Delrieu et al., 2009b].

\section{Hydrometeorological Products}

[19] A number of hydrometeorological products are generated: rainfall maps obtained from rain gauge networks by kriging (section 4.1) and radar/rain gauge quantitative precipitation estimates (QPE) (section 4.2).

\subsection{Rainfall Maps Obtained by the Kriging Technique}

[20] From rainfall time series, and for events for which at least $50 \mathrm{~mm} / \mathrm{d}$ was recorded somewhere in the CévennesVivarais window, CVMHO produces rainfall maps at different time steps (from hourly to the event time step). Among the interpolation techniques, the Kriging technique [Goovaerts, 1997] was chosen because it takes into account the spatial structure of the studied variable and provides an estimate of the uncertainty for each interpolated value. Spherical variogram functions are currently used to model the spatial structure of the rain fields for each event, with zero-nugget effect and a range set of $25 \mathrm{~km}$ for the hourly time step according to the climatology established by Lebel et al. [1987]. For the event time step, the range is fitted manually.

\subsection{Radar and Rain Gauge Quantitative Precipitation Estimates}

[21] A regionalized and adaptive radar data processing system [Delrieu et al., 2009b] has been developed since 2002 to process the $3-\mathrm{D}$ radar data. This processing is essentially composed of (1) a clutter identification technique based on the pulse-to-pulse variability of reflectivity and the use of dry weather clutter maps, (2) a coupled identification procedure for determining both a rain partition between convective and widespread rainfall and the associated vertical profiles of reflectivity (VPR), and (3) a method for estimating reflectivity at ground level from reflectivities measured aloft. This first processing step aims at correcting for range-dependent effects; it is based on radar data alone. To convert reflectivities $(Z)$ to rain rates $(R)$, rain typed $Z-R$ relationships from the literature or derived from drop size distribution measurements may be used. In order to control the bias and conditional bias of radar QPE, we perform an optimization of a single "effective" $Z-R$ relationship for each event based on radar-rain gauge comparisons over a range of time scales [Bouilloud et al., 2010]. This technique has been used to reanalyze rainfall for major events that occurred in southern France since 1997.

\section{System for Data Extraction and Visualization on Line}

[22] Système d'Extraction et de Visualisation des Données de l'Observatoire en Ligne (SEVnOL) is a Web interface developed to view and extract data, metadata and products in several formats (XML, CSV, NetCDF) over a user-defined spatial and temporal window. A screen capture of the Web interface is presented in Figure 2. Using asynchronous JavaScript and XML (AJAX) technology and compatible with most Web browsers, this system is based on the Google Maps interface. 

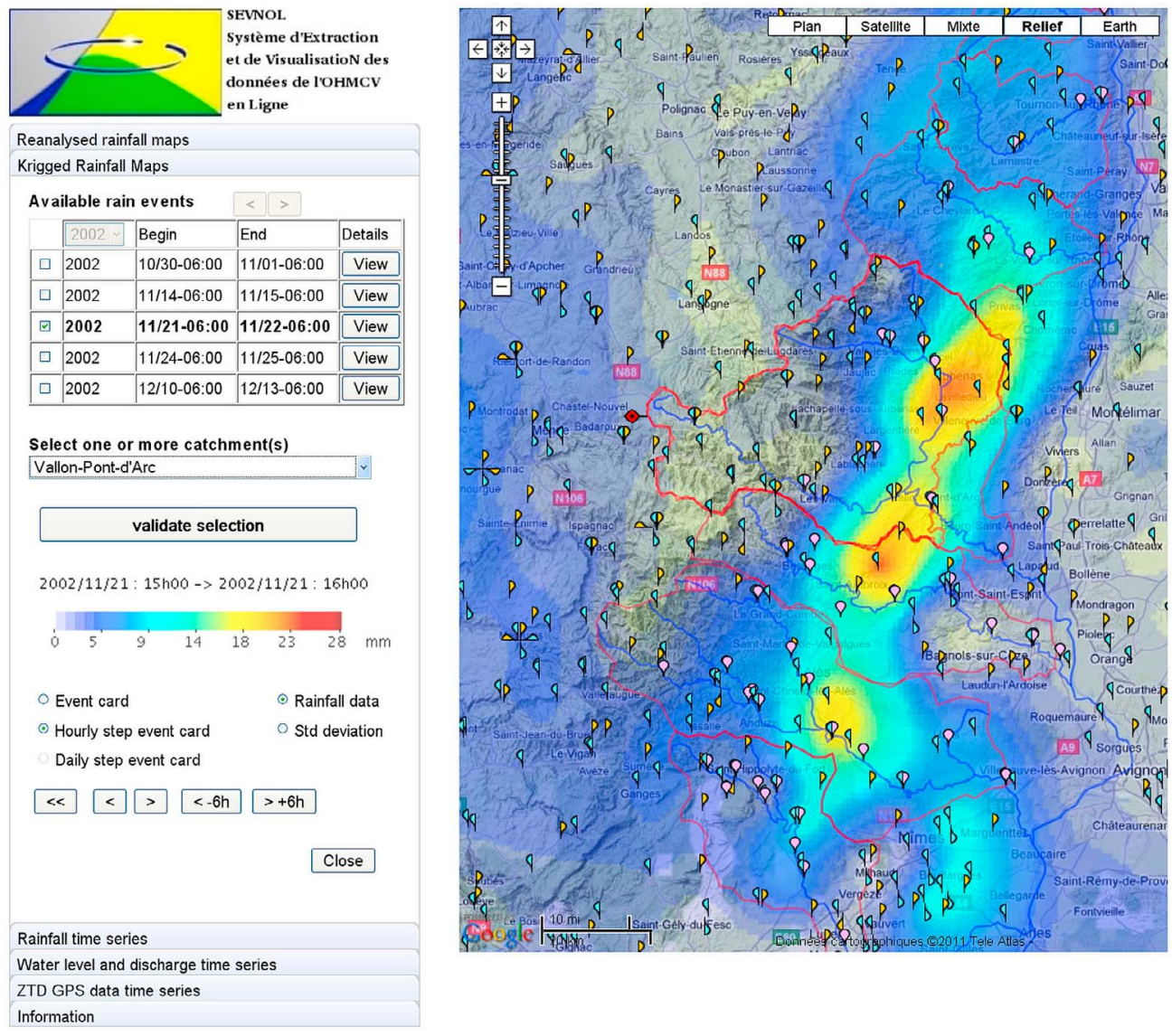

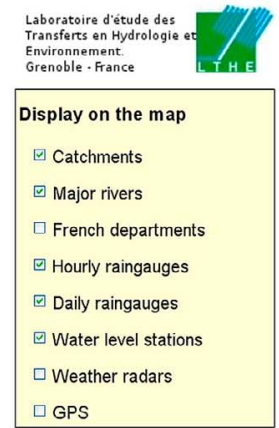

\section{Map Legend}

$P P:$ Water level stations

$P$ : Daily raingauges

I : Hourly raingauges

$P:$ Weather radars

PP: GPS

- : Catchments or French departments

Figure 2. Screen capture of the system developed for online viewing and data extraction. The screen shows a map of an hourly kriged rainfall with the contours of the major catchments, as well as the network of rain gauge and water level stations.

[23] The viewable products include time series of rainfall, water levels and discharges from operational networks after critical analysis, as well as rainfall maps obtained by kriging for all fall events over the period 2000-2008 at an hourly and event time step. The system also offers radar and rain gauge reanalyses with a time step of $15 \mathrm{~min}$ for major events. The rainfall maps and the water levels and discharge time series can be downloaded free of charge and without restriction. Data and products related to research experiments will be gradually added to the SEVnOL system. SEVnOL is accessible from the CVMHO Web site at http:// www.ohmcv.fr/.

\section{Future Developments and Perspectives}

[24] CVMHO provides the results of data critical analysis, collects and summarizes information concerning malfunctions and updates on its Web site. The data and products have already been used in many research studies. More than one hundred scientific papers in connection with CVMHO have been published in recent years. They concern several research questions, for example: the spatial and temporal variability of rainfall [Berne et al., 2009], the runoff genesis processes over a range of scales [Tramblay et al., 2011; Manus et al., 2009], the implementation and the value added of coupled hydrometeorological modeling [Vincendon et al., 2009], the frequency characterization of rain and floods
[Naulet et al., 2005], the study of the sociological vulnerability [Ruin et al., 2008], etc. The list of publications related to the database is frequently updated on the Web site.

[25] CVMHO's activities will continue over the coming decade which corresponds to the long observation period of the HyMeX project (see the International Science Plan on the project Web site, http://www.hymex.org/), a multidisciplinary study of the Mediterranean water cycle. The observation system is being gradually expanded with research experiments (locations of some of the sites are plotted in Figure 1) aimed at studying hydrometeorological processes. The research instrumentation will be further developed, especially in the next four years corresponding to the HyMeX enhanced observation periods (EOPs). Developments will include the following.

[26] 1. Documentation of precipitation characteristics with the deployment of dense precipitation observation networks (including $\mathrm{X}$ band and $\mathrm{C}$ band polarimetric radars, network of disdrometers and lightning detection sensors). Note that two disdrometers have already been operating in the Cévennes-Vivarais region [Chapon et al., 2008; Hazenberg et al., 2011] since 2004 and 2006. A station of the LINET lightning detection network was also setup in Alès in 2009.

[27] 2. Assessment of atmospheric water vapor based on the GPS zenith time delay (ZTD) data. The corresponding network deployed over the last decade [Champollion et al., 
2004; Brenot et al., 2006; Boniface et al., 2009] will be consolidated in coming years.

[28] 3. Observation of hydrological processes on the socalled "supersites" (small research catchments) of the CVMHO located in the Gard catchment at Valescure and Tourgueille [Cosandey et al., 2005; Brunet et al., 2010] and in the Ardèche catchment at Le Pradel. Observation at these sites includes standard hillslope hydrology measurements, the use of hydrogeophysical techniques to monitor the subsoil and discharge measurements over nested watersheds.

[29] 4. Multiscale monitoring of flood dynamics and underground hydrodynamics in karstic systems on the MEDYCYSS observatory sites, which includes three sites in the region of Montpellier: the Lez, Mosson and Colazou catchments [Bailly-Comte et al., 2008; Fleury et al., 2009].

[30] 5. Development of local remote sensing techniques for discharge measurement during floods using particle image velocimetry or radar techniques [Hauet et al., 2008; Le Coz et al., 2010]. Initial experiments are being carried out in the Ardèche catchment at three sites: Jaujac, Vals and Sauze.

[31] Data or metadata from these experiments will be made available as soon as possible via the Web system presented in section 5 .

[32] Acknowledgments. CVMHO is supported by the Institut National des Sciences de l'Univers (INSU/CNRS), the French Ministry for Education and Research, the Environment Research Cluster of the Rhône-Alpes Region, and the Observatoire des Sciences de l'Univers de Grenoble (OSUG/Grenoble University). The authors thank the providers of operational data: Météo-France, Electricité de France, and the SPC Grand Delta. We warmly thank colleagues of LTHE, including Ph.D. students and computing staff, who helped in creating, updating, organizing, and maintaining the database. We especially thank Pierre-Alain Ayral (École des Mines d'Alès) and the technical support of LTHE for the maintenance of DSD measurements. We finally thank Marlène Villanova-Oliver and Jérôme Gensel (Laboratoire d'Informatique de Grenoble, a laboratory specialized in computer sciences) for their participation in developing the early versions of SEVnOL.

\section{References}

Bailly-Comte, V., H. Jourde, A. Roesch, S. Pistre, and C. Batiot-Guilhe (2008), Time series analyses for karst/river interactions assessment: Case of the Coulazou River (southern France), J. Hydrol., 349, 98-114, doi:10.1016/j.jhydrol.2007.10.028.

Berne, A., G. Delrieu, and B. Boudevillain (2009), Variability of the spatial structure of intense Mediterranean precipitation, Adv. Water Resour., 32, 1031-1042, doi:10.1016/j.advwatres.2008.11.008.

Boniface, K., X. Yan, C. Champollion, V. Ducrocq, G. Jaubert, F. Masson, J. Chery, and E. Doerflinger (2009), Impact of high-resolution data assimilation of GPS zenith delay on Mediterranean heavy rainfall forecasting, Ann. Geophys., 27, 2739-2753, doi:10.5194/angeo-27-27392009.

Bouilloud, L., G. Delrieu, B. Boudevillain, and P.-E. Kirstetter (2010), Radar rainfall estimation in the context of post-event analysis of flash floods, J. Hydrol., 394, 17-27, doi:10.1016/j.jhydrol.2010.02.035.

Braud, I., H. Roux, S. Anquetin, M.-M. Maubourguet, C. Manus, P. Viallet, and D. Dartus (2010), The use of distributed hydrological models for the Gard 2002 flash flood event: Analysis of associated hydrological processes, J. Hydrol., 394, 162-181, doi:10.1016/j.jhydrol.2010.03.033.

Brenot, H., V. Ducrocq, A. Walpersdorf, C. Champollion, and O. Caumont (2006), GPS zenith delay sensitivity evaluated from high-resolution numerical weather prediction simulations of the 8-9 September 2002 flash flood over southeastern France, J. Geophys. Res., 111, D15105, doi:10.1029/2004JD005726.

Brunet, P., R. Clément, and C. Bouvier (2010), Monitoring soil water content and deficit using electrical resistivity tomography (ERT) - A case study in the Cevennes area, France, J. Hydrol., 380, 146-153, doi:10.1016/j.jhydrol.2009.10.032.

Champollion, C., F. Masson, J. Van Baelen, A. Walpersdorf, J. Chéry, and E. Doerflinger (2004), GPS monitoring of the tropospheric water vapor distribution and variation during the 9 September 2002 torrential precipitation episode in the Cévennes (southern France), J. Geophys. Res., 109, D24102, doi:10.1029/2004JD004897.

Chapon, B., G. Delrieu, M. Gosset, and B. Boudevillain (2008), Variability of rain drop size distribution and its effect on the $Z-R$ relationship: A case study for intense Mediterranean rainfall, Atmos. Res., 87, 52-65, doi:10.1016/j.atmosres.2007.07.003.

Cœur, D., and M. Lang (2008), Use of documentary sources on past flood events for flood risk management and land planning, C. R. Geosci., 340, 644-650, doi:10.1016/j.crte.2008.03.001.

Cosandey, C., V. Andréassian, C. Martin, J. F. Didon-Lescot, J. Lavabre, N. Folton, N. Mathys, and D. Richard (2005), The hydrological impact of the Mediterranean forest: A review of French research, J. Hydrol., 301, 235-249, doi:10.1016/j.jhydrol.2004.06.040.

Delrieu, G., et al. (2005), The catastrophic flash-flood event of 8-9 September 2002 in the Gard region, France: A first case study for the Cévennes-Vivarais Mediterranean Hydrometeorological Observatory, J. Hydrometeorol., 6, 34-52, doi:10.1175/JHM-400.1.

Delrieu, G., et al. (2009a), Weather radar and hydrology (preface), $A d v$. Water Resour., 32, 969-974, doi:10.1016/j.advwatres.2009.03.006.

Delrieu, G., B. Boudevillain, J. Nicol, B. Chapon, P.-E. Kirstetter, H. Andrieu, and D. Faure (2009b), Bollène 2002 experiment: Radar rainfall estimation in the Cévennes-Vivarais region, J. Appl. Meteorol. Climatol., 48, 1422-1447, doi:10.1175/2008JAMC1987.1.

Fleury, P., B. Ladouche, Y. Conroux, H. Jourde, and N. Dörfliger (2009), Modelling the hydrologic functions of a karst aquifer under active water management-The Lez spring, J. Hydrol., 365, 235-243, doi:10.1016/j. jhydrol.2008.11.037.

Gaume, E., and M. Borga (2008), Post flood field investigations after major flash floods: Proposal of a methodology and illustrations, J. Flood Risk Manage., 1, 175-189, doi:10.1111/j.1753-318X.2008.00023.x.

Goovaerts, P. (1997), Geostatistics for Natural Resources Evaluation, 483 pp., Oxford Univ. Press, New York.

Hauet, A., A. Kruger, W. F. Krajewski, A. Bradley, M. Muste, J.-D. Creutin, and M. Wilson (2008), Experimental system for real-time discharge estimation using an image-based method, J. Hydrol. Eng., 13, 105-110, doi:10.1061/(ASCE)1084-0699(2008)13:2(105).

Hazenberg, P., N. Yu, B. Boudevillain, G. Delrieu, and R. Uijlenhoet (2011), Scaling of raindrop size distributions and classification of radar reflectivity-rain rate relations in intense Mediterranean precipitation, J. Hydrol., 402, 179-192, doi:10.1016/j.jhydrol.2011.01.015.

Kirstetter, P. E., G. Delrieu, B. Boudevillain, and C. Obled (2010), Toward an error model for radar quantitative precipitation estimation in the Cévennes-Vivarais region, France, J. Hydrol., 394, 28-41, doi:10.1016/ j.jhydrol.2010.01.009.

Lang, M., K. Pobanz, B. Renard, E. Renouf, and E. Sauquet (2010), Extrapolation of rating curves by hydraulic modelling, with application to flood frequency analysis, Hydrol. Sci. J., 55(6), 883-898, doi: $10.1080 / 02626667.2010 .504186$.

Lebel, T., G. Bastin, C. Obled, and J. D. Creutin (1987), On the accuracy of areal rainfall estimation: A case study, Water Resour. Res., 23(11), 2123-2134, doi:10.1029/WR023i011p02123.

Le Coz, J., A. Hauet, G. Pierrefeu, G. Dramais, and B. Camenen (2010), Performance of image-based velocimetry (LSPIV) applied to flash-flood discharge measurements in Mediterranean rivers, J. Hydrol., 394, 42-52, doi:10.1016/j.jhydrol.2010.05.049.

Manus, C., S. Anquetin, I. Braud, J.-P. Vandervaere, J. D. Creutin, P. Viallet, and E. Gaume (2009), A modelling approach to assess the hydrological response of small Mediterranean catchments to the variability of soil characteristics in a context of extreme events, Hydrol. Earth Syst. Sci., 13, 79-97, doi:10.5194/hess-13-79-2009.

Marchi, L., M. Borga, E. Preciso, and E. Gaume (2010), Characterisation of selected extreme flash floods in Europe and implications for flood risk management, J. Hydrol., 394, 118-133, doi:10.1016/j.jhydrol. 2010.07.017.

Naulet, R., M. Lang, T.-B. Ouarda, D. Cœur, B. Bobee, A. Recking, and D. Moussay (2005), Flood frequency analysis on the Ardèche River using French documentary sources from the two last centuries, J. Hydrol., 313, 58-78, doi:10.1016/j.jhydrol.2005.02.011.

Nuissier, O., V. Ducrocq, D. Ricard, C. Lebeaupin, and S. Anquetin (2008), A numerical study of three catastrophic precipitating events over 
southern France. I: Numerical framework and synoptic ingredients, $Q . J . R$. Meteorol. Soc., 134, 111-130, doi:10.1002/qj.200.

Pellarin, T., G. Delrieu, G. M. Saulnier, H. Andrieu, B. Vignal, and J.-D Creutin (2002), Hydrologic visibility of weather radar systems operating in mountainous regions: Case study for the Ardèche catchment (France), J. Hydrometeorol., 3, 539-555, doi:10.1175/1525-7541(2002) $003<0539$ :HVOWRS $>2.0$. CO 2 .

Ruin, I., J. D. Creutin, S. Anquetin, and C. Lutoff (2008), Human exposure to flash floods-Relation between flood parameters and human vulnerability during a storm of September 2002 in southern France, J. Hydrol., 361, 199-213, doi:10.1016/j.jhydrol.2008.07.044.

Sheffer, N. A., Y. Enzel, G. Benito, T. Grodek, N. Poart, M. Lang, R. Naulet, and D. Cœur (2003), Paleofloods and historical floods of the Ardèche River, France, Water Resour. Res., 39(12), 1376, doi:10.1029/ 2003WR002468.

Tabary, P. (2007), The new French operational radar rainfall product: Part I, methodology, Weather Forecast., 22, 393-408, doi:10.1175/WAF1004.1.
Tramblay, Y., C. Bouvier, P. A. Ayral, and A. Marchandise (2011), Impact of rainfall spatial distribution of rainfall-runoff modelling efficiency and initial soil moisture conditions estimation, Nat. Hazards Earth Syst. Sci., 11, 157-170, doi:10.5194/nhess-11-157-2011.

Vincendon, B., et al. (2009), Flash-flood forecasting within the PREVIEW project: Value of high-resolution hydrometeorological coupled forecast, Meteorol. Atmos. Phys., 103, 115-125, doi:10.1007/s00703-008-0315-6.

L. Bonnifait, B. Boudevillain, L. Bouilloud, G. Delrieu, B. Galabertier, and P.-E. Kirstetter, UJF Grenoble 1/CNRS/G-INP/IRD, Laboratoire d'Étude des Transferts en Hydrologie et Environnement, UMR 5564, Grenoble, F-38041, France. (brice.boudevillain@ujf-grenoble.fr)

M.-L. Mosini, Département Géotechnique, Eau and Risques, IFSTTAR, Bouguenais, F-44341, France. 